\title{
Measurement and Evaluation of Income Distribution Gap -Taking the Tibetan Regions in Qinghai as an Example
}

\author{
Tong Lei, Jian Wang* \\ School of Finance and Economics, Qinghai University \\ Xining City, Qinghai Province, China \\ Email: 1098636097@qq.com
}

\begin{abstract}
The basic situation of social and economic development of the Tibetan Regions in Qinghai, the largest area in Tibetan region with the largest Tibetan population and more concentrated residents, directly determines the final effect of the implementation of "the Four-Pronged Comprehensive Strategy" proposed by the central government, therefore, it is imperative to conduct a detailed study of the income distribution gap issue in Tibetan regions. Based on the original research results, this paper selects extreme value difference, extreme value ratio, standard deviation, coefficient of variation, Theil index and other indicators to measure and evaluate the income distribution gap in the Tibetan Regions in Qinghai, and come to the conclusion that the income distribution gap in various areas of the Tibetan Regions in Qinghai are widening year by year and the trends of expansion among different regions are different through the intra-regional, inter-regional, horizontal and vertical comparisons of the Tibetan Regions in Qinghai, thus providing new ideas for the reform of income distribution in the Tibetan Regions in Qinghai.
\end{abstract}

Keywords-Qinghai Tibetan area; Income gap; Coefficient of Variation; Theil index

\section{INTRODUCTION}

Due to the weak economic foundation in the Tibetan Regions in Qinghai, the occluded information and the inconvenient transportation leads to the underdeveloped market economy, the weak main market player and the imperfectly developed social organization. In remote agricultural and pastoral areas, the self-sufficient natural economy still occupies a considerable proportion, which hinders and restricts the social development of the Tibetan region to a certain extent and also has a great impact on the income distribution of the Tibetan Regions in Qinghai. The measurement and evaluation of the income distribution gap in the Tibetan Regions in Qinghai play an important role in the rational redistribution of the income of residents in the Tibetan Regions in Qinghai and the promotion of the social equity in the entire Tibetan region.

The possible contributions of this article are as follows: Firstly, based on the original research results, this article summarizes a relatively simple indicator system for evaluating the income distribution gap, which provides new ideas for other scholars to conduct social equity research in remote ethnic minority areas. Secondly, at present, there are relatively few studies on the income distribution of remote ethnic minority areas in China, this article provides other scholars with new ideas when researching the income distribution issue in the remote national minority areas with the analysis methods such as the combination method of static analysis and dynamic analysis and the combination method of local analysis and overall analysis. Finally, this article finds the key factors leading to the income distribution gap in the Tibetan Regions in Qinghai through the analysis of the collected data, which has guiding significance for the reasonable redistribution of residents' income in the Tibetan Regions in Qinghai.

\section{MEASUREMENT OF INCOME DISTRIBUTION GAP OF RESIDENTS IN THE TIBETAN REGIONS IN QINGHAI}

\section{A. Indicators for measuring the income distribution gap}

In the field of economics, there are many indicators for measuring the income distribution gap, this article conducts the measurement and calculation [1] with extreme value difference, extreme value ratio, standard deviation, coefficient of variation, Theil index and other indicators in order to facilitate static and dynamic analysis when measuring the income distribution gap in the Tibetan Regions in Qinghai

\section{B. Analysis of the income distribution gap of farmers and herdsmen in the Tibetan Regions in Qinghai}

With the development of the commodity economy and the reform of the social economic system, the income gaps between the Tibetan Regions in Qinghai and non-Tibetan region and between the Tibetan Regions in Qinghai and the internal Tibetan region have been expanding year by year. In general, the income level of residents in the Tibetan Regions in Qinghai has been increasing generally and the income gap has been expanding year by year. The proportion of the low-income population in rural areas has been decreasing year by year, and the number of the high-income population has been increasing year by year, but the per capita annual income level is significantly lower than that of urban residents. The disposable income of urban residents in the Tibetan Regions in Qinghai has been increasing year by year, and the increase rate is higher than that of the net income of the rural residents [2].

The analysis and measurement of the income distribution gap of residents in the Tibetan Regions in Qinghai are shown in the following chart: 
TABLE I MEASUREMENT OF NET INCOME GAP BETWEEN FARMERS AND HERDSMEN IN THE TiBETAN REGIONS IN QINGHAI

UNIT: YUAN

\begin{tabular}{|c|c|c|c|c|c|c|c|c|}
\hline & & $\begin{array}{l}\text { Measurement } \\
\text { herdsmen }\end{array}$ & of the net in & ne gap between fa & mers and & & & \\
\hline Year & Maximum & $\begin{array}{l}\text { Region with the } \\
\text { maximum } \\
\text { value }\end{array}$ & Minimum & $\begin{array}{l}\text { Region with the } \\
\text { minimum value }\end{array}$ & Range & $\begin{array}{l}\text { Extreme } \\
\text { value ratio }\end{array}$ & $\begin{array}{l}\text { Standard } \\
\text { deviation }\end{array}$ & $\begin{array}{l}\text { Coefficient of } \\
\text { variation }\end{array}$ \\
\hline 2010 & 5434 & $\begin{array}{c}\text { Haixi } \\
\text { Prefecture }\end{array}$ & 2629 & $\begin{array}{l}\text { Guoluo } \\
\text { Prefecture }\end{array}$ & 2805 & 2.07 & 909 & 0.77 \\
\hline 2011 & 6574 & $\begin{array}{c}\text { Haixi } \\
\text { Prefecture }\end{array}$ & 2657 & $\begin{array}{r}\text { Yushu } \\
\text { Prefecture }\end{array}$ & 3917 & 2.47 & 1403 & 0.85 \\
\hline 2012 & 7916 & $\begin{array}{c}\text { Haixi } \\
\text { Prefecture }\end{array}$ & 3493 & $\begin{array}{r}\text { Yushu } \\
\text { Prefecture }\end{array}$ & 4422 & 2.27 & 1587 & 0.85 \\
\hline 2013 & 9183 & $\begin{array}{c}\text { Haixi } \\
\text { Prefecture }\end{array}$ & 4090 & $\begin{array}{r}\text { Yushu } \\
\text { Prefecture }\end{array}$ & 5093 & 2.25 & 1845 & 0.85 \\
\hline 2014 & 10294 & $\begin{array}{c}\text { Haixi } \\
\text { Prefecture }\end{array}$ & 4638 & $\begin{array}{r}\text { Yushu } \\
\text { Prefecture }\end{array}$ & 5656 & 2.22 & 2048 & 0.85 \\
\hline 2015 & 11025 & $\begin{array}{c}\text { Haixi } \\
\text { Prefecture }\end{array}$ & 5023 & $\begin{array}{r}\text { Yushu } \\
\text { Prefecture }\end{array}$ & 6002 & 2.20 & 2198 & 0.86 \\
\hline
\end{tabular}

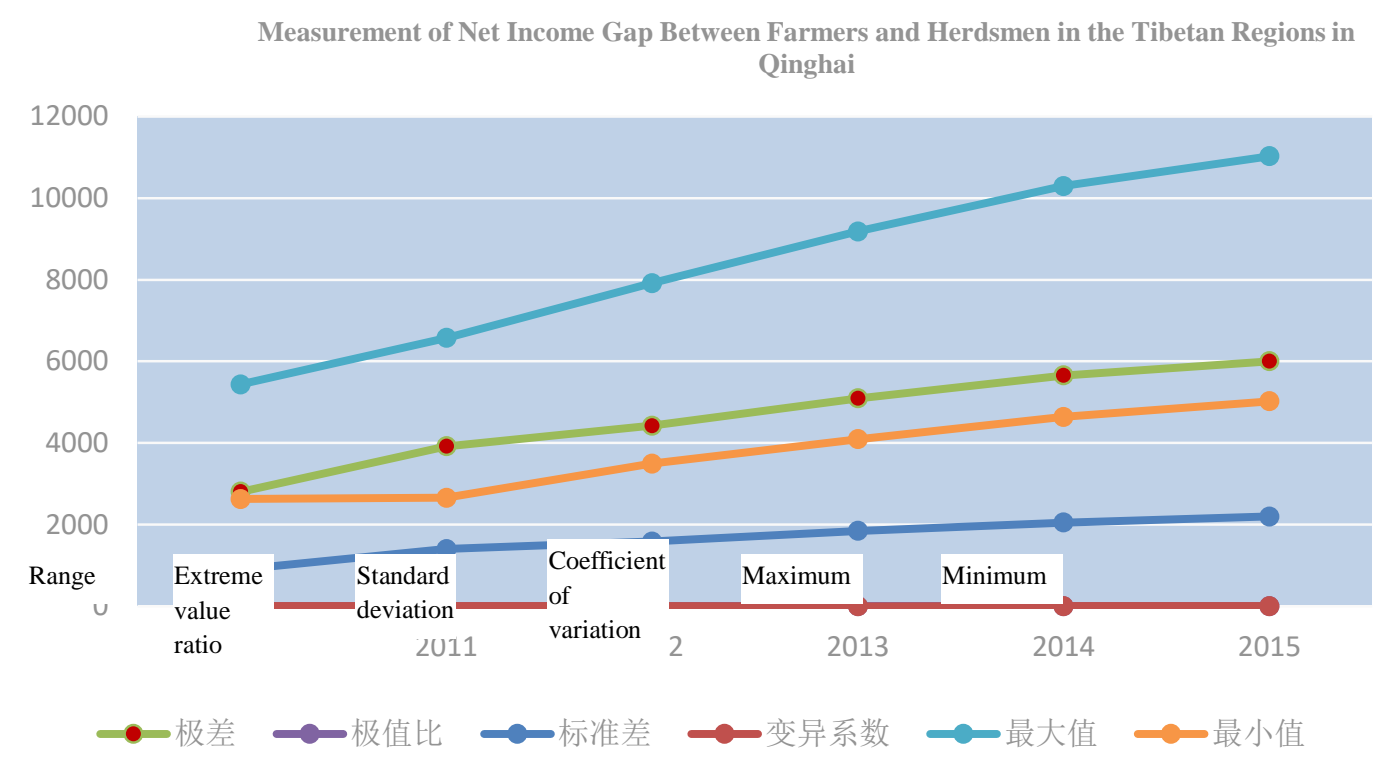

Fig. 1 Trends in the Net Income Gap between Farmers and Herdsmen in the Tibetan Regions in Qinghai

It can be seen from the above chart, from 2011 to 2015 , each indicator for measuring the net income gap between farmers and herdsmen in the Tibetan Regions in Qinghai was gradually increased, among which, the income level of farmers and herdsmen in Haixi Prefecture was highest, and the gaps between its income level and the income levels of Yushu Prefecture and Guoluo Prefecture where the income levels were lowest were increased in both absolute value and relative value.

\section{Analysis of the income distribution gap of urban residents} in the Tibetan Regions in Qinghai

The urban residents of the Tibetan Regions in Qinghai belong to different areas within the Tibetan Region, who are mainly living in cities and towns. Although there are many income sources and channels of urban residents in the Tibetan Regions in Qinghai and the income structure is relatively stable, due to differences in natural conditions and geographical locations, there are certain gaps between different 
regions. The article analyzes the disposable income gap of urban residents in the Tibetan Regions in Qinghai with the indicators such as the range between the regions [3], and the specific calculation results are as follows (Table 2):

TABLE II MEASUREMENT OF THE Disposable Income GAP OF URBAN RESIDENTS IN THE TIBETAN REGIONS IN QINGHAI UNIT: YuAN

\begin{tabular}{|c|c|c|c|c|c|c|c|c|}
\hline & & $\begin{array}{l}\text { Measurement } 0 \\
\text { Residents }\end{array}$ & the Dispo & able Income Gap o & Urban & & & \\
\hline Year & Maximum & $\begin{array}{l}\text { Region with the } \\
\text { maximum value }\end{array}$ & Minimum & $\begin{array}{l}\text { Region with the } \\
\text { maximum value }\end{array}$ & Range & $\begin{array}{l}\text { Extreme } \\
\text { value ratio }\end{array}$ & $\begin{array}{l}\text { Standard } \\
\text { deviation }\end{array}$ & $\begin{array}{l}\text { Coefficient of } \\
\text { variation }\end{array}$ \\
\hline 2010 & 16759 & $\begin{array}{c}\text { Haixi } \\
\text { Prefecture }\end{array}$ & 12554 & $\begin{array}{l}\text { Hainan } \\
\text { Prefecture }\end{array}$ & 4205 & 1.34 & 14882.22 & 0.10 \\
\hline 2011 & 19007 & $\begin{array}{c}\text { Haixi } \\
\text { Prefecture }\end{array}$ & 14652 & $\begin{array}{l}\text { Hainan } \\
\text { Prefecture }\end{array}$ & 4355 & 1.30 & 1526.90 & 0.10 \\
\hline 2012 & 21252 & $\begin{array}{c}\text { Haixi } \\
\text { Prefecture }\end{array}$ & 16557 & $\begin{array}{l}\text { Hainan } \\
\text { Prefecture }\end{array}$ & 4695 & 1.25 & 1655.92 & 0.11 \\
\hline 2013 & 23399 & $\begin{array}{c}\text { Haixi } \\
\text { Prefecture }\end{array}$ & 18657 & $\begin{array}{l}\text { Hainan } \\
\text { Prefecture }\end{array}$ & 4742 & 1.27 & 1660.30 & 0.11 \\
\hline 2014 & 25453 & $\begin{array}{c}\text { Haixi } \\
\text { Prefecture }\end{array}$ & 20568 & $\begin{array}{l}\text { Hainan } \\
\text { Prefecture }\end{array}$ & 4885 & 1.29 & 1672.61 & 0.12 \\
\hline 2015 & 27896 & $\begin{array}{c}\text { Haixi } \\
\text { Prefecture }\end{array}$ & 22666 & $\begin{array}{l}\text { Hainan } \\
\text { Prefecture }\end{array}$ & 5230 & 1.32 & 1819.66 & 0.12 \\
\hline
\end{tabular}

Measurement of the disposable income of urban residents in the Tibetan regions in Qinghai

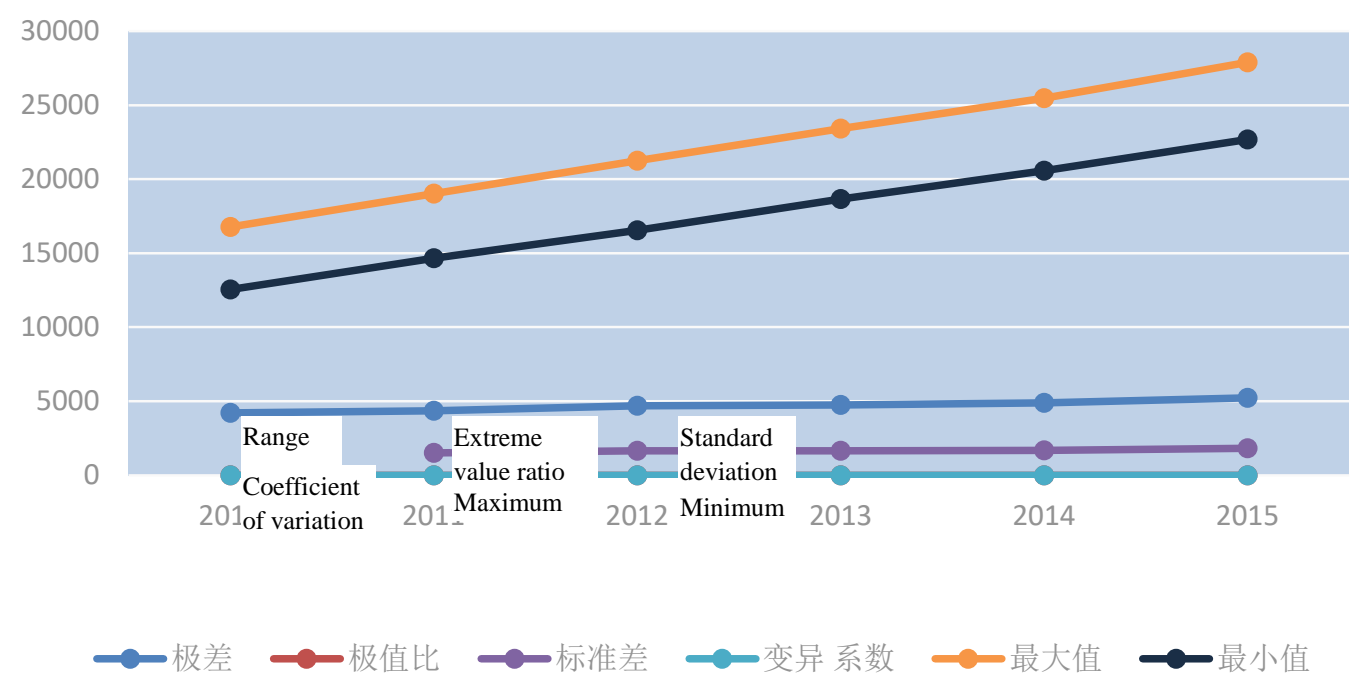

Fig. 2 Measurement of the Change Trends of the Disposable Income Gap of Urban Residents in the Tibetan Regions in Qinghai

It can be seen from Table 2 that the disposable income of urban residents in Haixi Prefecture (in the Tibetan Regions in Qinghai) was highest, and that in Hainan Prefecture was lowest. In 2011, the gap between the two regions in the disposable income was RMB 4,205, and by the end of the "Twelfth Five-Year Plan" period, the gap between the two regions in the disposable income reached RMB 5,230. Even though the incomes in the two regions have been increased, the income gap has been gradually expanding. It can be seen that the income gap between regions has been gradually expanding with the increase in per capita disposable income of urban residents in the Tibetan Regions in Qinghai.

\section{ANALYSIS OF THE INCOME DISTRIBUTION GAP BETWEEN DIFFERENT REGIONS IN QINGHAI}

A. Static Analysis of the Income Distribution Gap between Different Regions

In recent years, although the urban and rural incomes in the Tibetan Regions in Qinghai have been increased substantially, the internal urban-rural gap is still higher, and the following 
text will analyze the urban-rural income gap among various prefectures in 2015.

TABLE III URBan-RURAL InCOME GAP IN THE ETHNIC MinORITy AREAS IN QINGHAi IN 2015

\begin{tabular}{|c|c|c|c|c|}
\hline & $\begin{array}{l}\text { Disposable Income } \\
\text { Urban Residents (Yuan) }\end{array}$ & $\begin{array}{l}\text { of Net Income of Farmers } \\
\text { and Herdsmen (Yuan) }\end{array}$ & $\begin{array}{l}\text { Income Difference } \\
\text { Urban and Rural } \\
\text { (Yuan) }\end{array}$ & $\begin{array}{l}\text { between } \\
\text { Residents } \\
\text { and Rural Residents }\end{array}$ \\
\hline $\begin{array}{l}\text { Haibei } \\
\text { Prefecture }\end{array}$ & 27204 & 6150 & 21054 & $2.77: 1$ \\
\hline $\begin{array}{l}\text { Huangnan } \\
\text { Prefecture }\end{array}$ & 24955 & 5238 & 19717 & $2.86: 1$ \\
\hline $\begin{array}{l}\text { Hainan } \\
\text { Prefecture }\end{array}$ & 22666 & 3650 & 19016 & $3.32: 1$ \\
\hline $\begin{array}{l}\text { Guoluo } \\
\text { Prefecture }\end{array}$ & 23759 & 2964 & 20795 & $4.35: 1$ \\
\hline $\begin{array}{l}\text { Yushu } \\
\text { Prefecture }\end{array}$ & 25588 & 2657 & 22931 & 4.60:1 \\
\hline $\begin{array}{l}\text { Haixi } \\
\text { Prefecture }\end{array}$ & 27896 & 6574 & 21322 & $2.63: 1$ \\
\hline
\end{tabular}

It can be seen from Table 3 that the gap between the disposable income of urban residents and the net income of farmers and herdsmen in various prefectures in Qinghai Province is relatively large, with an average of about RMB 20,000; The gap in Yushu Prefecture is highest, and that in Hainan Prefecture is lowest. Among various prefectures, the disposable income of urban residents in Haixi Prefecture was highest, and that in Hainan Prefecture was lowest, with a difference of RMB 5,230. The net income of farmers and herdsmen in Haixi Prefecture was highest and that in Yushu Prefecture was lowest, with a difference of RMB 3,917. From the above analysis, it can be seen that the income gap between urban residents is larger than that between rural residents; The income gap between urban and rural residents and the income ratio of urban and rural residents in Yushu Prefecture were highest, and those in Hainan Prefecture were lowest. On the whole, due to relatively remote geographical position, higher altitude and low economic vitality, the income level of urban and rural residents in Yushu Prefecture was lower; Due to the relatively developed industry and agriculture in Haixi Prefecture, the income level of urban and rural residents was higher.
In the specific ethnic autonomous areas, the phenomenon that the disposable income of urban residents is significantly higher than the net income of the farmers is very common, for example, the disposable income of urban residents in the Yushu Tibetan Autonomous Prefecture in 2015 was RMB 25,588 , the net income of rural residents was RMB 5,565, and the former was 4.60 times of the latter. For example, the disposable income of urban residents in the Hainan Tibetan Autonomous Prefecture and that of urban residents in the Guoluo Tibetan Autonomous Prefecture was 3.32 times and 4.35 times of the net income of rural residents. Although the greater the gap, the more it can indicate the economy in this area is in a period of rapid development, such a large income gap will also bring more social hidden dangers to the local area.

\section{B. Dynamic Analysis of the Income Distribution Gap between Different Regions}

In order to more clearly understand the income gap among various prefectures in the Tibetan Regions in Qinghai, the following text will conduct the analysis after decomposing the general differences indicators in the Tibetan Regions in Qinghai into the difference among the six prefectures and the difference within various prefectures with the Theil index. 
TABLE IV DECOMPOSITION AND ANALYSIS OF THE WhOLE THEIL INDEX IN THE TIBETAN REgIONS IN QINGHAI

\begin{tabular}{cccccc}
\hline Year & Theil index & $\begin{array}{c}\text { Gap within } \\
\text { prefectures }\end{array}$ & $\begin{array}{c}\text { Contribution } \\
\text { rate }(\%)\end{array}$ & $\begin{array}{c}\text { Gap among } \\
\text { prefectures }\end{array}$ & $\begin{array}{c}\text { Contribution } \\
\text { rate (\%) }\end{array}$ \\
\hline 2011 & 0.1183 & 0.0491 & 0.4865 & 0.0629 & 0.5135 \\
2012 & 0.1361 & 0.0572 & 0.4206 & 0.0798 & 0.5863 \\
2013 & 0.1127 & 0.0428 & 0.3798 & 0.0639 & 0.5670 \\
2014 & 0.1132 & 0.0412 & 0.364 & 0.0658 & 0.5813 \\
2015 & 0.1157 & 0.0436 & 0.3768 & 0.0616 & 0.5324 \\
\hline
\end{tabular}

Data source: According to the 2012-2016 Qinghai Statistical Yearbook

It can be seen from Table 4, the overall Theil index of the Tibetan Regions in Qinghai was increased in 2011-2012, and there was a downward trend in 2012-2013, but there was a slight upward trend in 2013-2015. It can be seen from this data that the income gap of residents in Tibetan region was generally expanded from 2011 to 2012, and the degree was more obvious; By 2013, the income gap of residents in Tibetan region was gradually decreased; Although there was an upward trend in the income gap in 2013-2015, the change was extremely small, and they were basically at the same level before and after the change. Through the analysis of the composition of the Theil index, the contribution rate of the gap among various prefectures is much higher than that within prefectures, and it can be seen that the income gap of the residents among various prefectures in the Tibetan region is significantly higher than that in various counties in various prefectures, i.e. the income gap of residents among various prefectures is the main reason that affects the income gap of the residents in the Tibetan Regions in Qinghai, but the difference in the income gap of residents in a single autonomous prefecture is not very large [4].

The following content is the dynamic analysis of the disposable income and the proportion of urban and rural residents in each region:

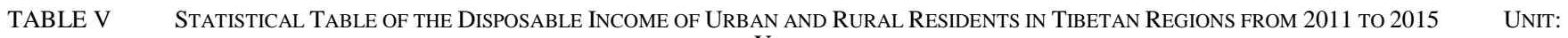
YUAN

\begin{tabular}{|c|c|c|c|c|c|c|c|c|c|c|c|c|c|c|c|}
\hline Year & \multicolumn{3}{|l|}{2011} & \multicolumn{3}{|c|}{2012} & \multicolumn{3}{|c|}{2013} & \multicolumn{4}{|c|}{2014} & \multicolumn{2}{|l|}{2015} \\
\hline 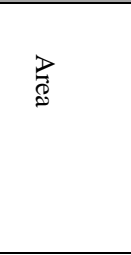 & 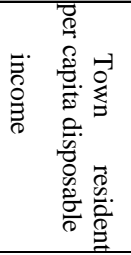 & 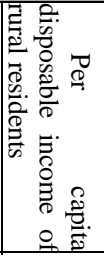 & 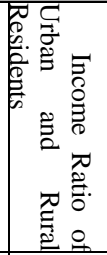 & 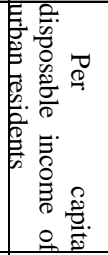 & 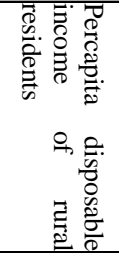 & 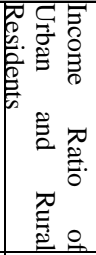 & 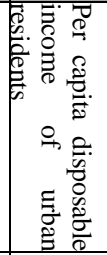 & 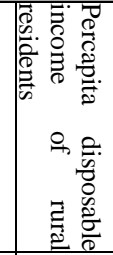 & 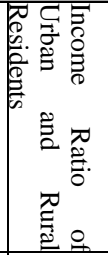 & 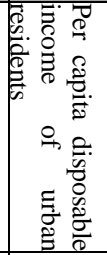 & 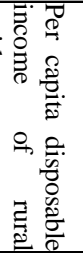 & 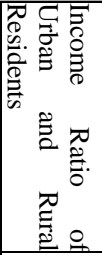 & 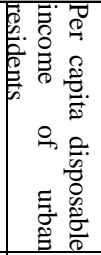 & 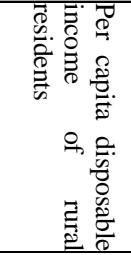 & 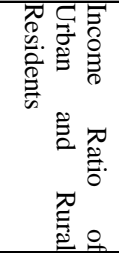 \\
\hline $\begin{array}{l}\text { Haibei } \\
\text { Prefecture }\end{array}$ & 18149.99 & 6150.1 & $2.95: 1$ & 18699 & 6919 & $2.99: 1$ & 20626 & 8048 & $2.83: 1$ & 22314 & 9049 & $2.73: 1$ & 24606 & 9836 & $2.77: 1$ \\
\hline $\begin{array}{l}\text { Huangnan } \\
\text { Prefecture }\end{array}$ & 16574.15 & 5237.5 & $3.17: 1$ & 18235 & 4781 & $3.05: 1$ & 20266 & 5550 & $2.92: 1$ & 22151 & 6288 & $2.82: 1$ & 24407 & 6819 & $2.86: 1$ \\
\hline $\begin{array}{l}\text { Hainan } \\
\text { Prefecture }\end{array}$ & 14652.07 & 3649.2 & $4.02: 1$ & 17557 & 6109 & $3.46: 1$ & 19783 & 7098 & $3.36: 1$ & 21810 & 8026 & $3.27: 1$ & 24025 & 8737 & $3.32: 1$ \\
\hline $\begin{array}{l}\text { Guoluo } \\
\text { Prefecture }\end{array}$ & 15299.4 & 2963.9 & $5.16: 1$ & 18868 & 3876 & $4.49: 1$ & 21243 & 4457 & $4.40: 1$ & 23457 & 5050 & $4.26: 1$ & 25762 & 5465 & $4.35: 1$ \\
\hline $\begin{array}{l}\text { Yushu } \\
\text { Prefecture }\end{array}$ & 17427.22 & 2657.0 & $6.59: 1$ & 18935 & 3870 & $4.88: 1$ & 21206 & 4531 & $4.67: 1$ & 23398 & 5138 & $4.54: 1$ & 25655 & 5565 & $4.60: 1$ \\
\hline $\begin{array}{l}\text { Haixi } \\
\text { Prefecture }\end{array}$ & 19006.95 & 6574.4 & $2.89: 1$ & 19369 & 7597 & $2.80: 1$ & 21326 & 8813 & $2.66: 1$ & 23198 & 9880 & $2.58: 1$ & 25419 & 10582 & $2.63: 1$ \\
\hline
\end{tabular}

With the economic development of Qinghai Province, the disposable income of each prefecture had been increased to varying degrees, but due to the differences in the natural conditions and economic development levels among various prefectures, the income growth rates were also different.
During the "Twelfth Five-Year Plan" period, the maximum income ratios of urban and rural residents in various prefectures were $2.99,3.17,4.02,5.16,6.59$ and 2.89 respectively, the maximum value in Haibei Prefecture appeared in 2012, the maximum values of other prefectures appeared in 
2011, and the gap between the income of urban and rural residents in various prefectures was more obvious. During this period, the income gap between urban and rural residents in Yushu Prefecture, Huangnan Prefecture and Guoluo Prefecture was generally higher, while that in other three autonomous prefectures was lower. In 2011, the income gap between urban and rural residents in Haibei Prefecture was lowest, but by 2015, the income gap in Haibei Prefecture was risen to second place, and that in Haixi Prefecture ranked first. In general, there was a downward trend in the proportion of urban and rural income in various Tibetan autonomous prefectures in Qinghai Province.

According to Table 5, the horizontal comparison has been firstly carried out, from 2011 to 2015, the proportion of urban and rural income in the Tibetan Regions in Qinghai was gradually expanded, and the changes in Haibei Prefecture were more obvious; Although there was a large gap between urban and rural areas in Huangnan Prefecture, the income gap between urban and rural areas varied little in each year, basically at about $3: 1$, the ratio during the minimum period was less than 0.05 , the main reason is that Huangnan Prefecture is located at the junction of the three provinces, i.e. Qinghai, Gansu and Sichuan, the traffic is inconvenient, the industrial structure is single, and the income level of urban and rural residents is growing slowly. Guoluo Prefecture and Yushu Prefecture are two prefectures with the largest income gap between urban and rural residents in the Tibetan region of Qinghai Province, this gap not only shows an expanding trend, but is also shown as the annual growth rate. In a particular national autonomous prefecture, the income gap between urban and rural residents is widespread. In general, the disposable income of urban residents is much higher than the net income of farmers and herdsmen. If the analysis is carried out with Guoluo Prefecture and Yushu Prefecture as examples, the natural conditions in most areas in Guoluo Prefecture and Yushu Prefecture are poor, the infrastructure in agricultural and pastoral areas is relatively poor, all of them can only adapt to the development of animal husbandry, and the source of income of the farmers is very single, therefore, the income gap between urban and rural residents is very large.

Secondly, if the vertical comparison is carried out, during the "Twelfth Five-Year Plan" period, the income levels of urban and rural residents in various prefectures in the Tibetan Regions in Qinghai were constantly increased, the income level of urban and rural residents in Haixi Prefecture ranked first, while that in Hainan Prefecture was in the last place, which was in line with the fact that the GDP of Haixi Prefecture ranked first while the GDP of Hainan Prefecture was in the last place. It shows that the faster the economic growth, the higher the level of per capita disposable income. It can be seen from the results calculated in Table 5 that the income gap between urban and rural residents in Huangnan Prefecture, Guoluo Prefecture and Yushu Prefecture was relatively large, the income gap between urban and rural residents among various prefectures was also obvious, and there was an expansion trend in the gap among various prefectures.

It can be seen from the whole chart that in the three autonomous prefectures, i.e. Haibei Prefecture, Haixi Prefecture and Huangnan Prefecture, the gap between urban and rural residents was higher and the gap ratio was less than 3 ; The income ratios of the three autonomous prefectures, i.e. Hainan, Guoluo and Yushu, were not reasonable, and although the income level of farmers and herdsmen had been increasing year by year, there was still a big gap compared with the income of urban residents. Among the various prefectures in Qinghai Province, the gap between urban and rural areas in high-altitude autonomous prefectures was most obvious, but there was a narrowing trend. Therefore, the relevant units should strengthen the policy support for farmers and herdsmen, so that they can have more sense of gain and a contribution can be made to the prosperity and stability of the ethnic minority areas.

\section{CONCLUSIONS}

Through the above analysis, we can know: In the five years from 2011 to 2015, the income distribution gap in the Tibetan Regions in Qinghai had been generally increasing year by year, and an expanding trend was also shown, but it had not caused obvious obstacles to economic development and it was in a relatively moderate range. On the other hand, the income distribution gap was highly adapted to the economic growth and it was also in an acceptable range. However, the main issues of economic development are still outstanding, manifested as the unreasonable resource allocation, the relatively slow growth rate of net income of farmers and herdsmen in Tibetan regions compared with the growth rate of net income of urban residents in Tibetan regions, the income gap in different regions has been further widened, which will have an adverse impact on the social equity in the Tibetan Regions in Qinghai. Therefore, narrowing the income distribution gaps between farmers \& herders and urban residents and between residents in different regions has become the key to comprehensively coordinate the income distribution mechanism.

\section{REFERENCES}

[1] Limin YANG and Liuliu KONG. The Impact of the Urbanization and Industrial Upgrading on the Urban-rural Income Gap [J]. China Business \& Trade. 2014, (26): 199-201.

[2] Jian WANG, Li XIE and Yanjie WANG. A Comparative Study on the Income Distribution Gaps of Different Ethnic Groups in the Tibetan Regions in Qinghai [J]. Nationalities Research In Qinghai. 2011, (4): 146-150.

[3] Qingong WEI. "Double Impression" in the Development Process: Study on the Income Inequality of Urban Residents in China [J]. Journal of Social Development. 2014, (03): 1-32.

[4] Jinwang YUAN, Xiaoyan LIU and Weijuan XUE. Exploration on the Income Gap between Urban and Rural Residents in Qingdao [J]. Shandong Trade Unions' Tribune 2014, 20 (06): 73-74. 